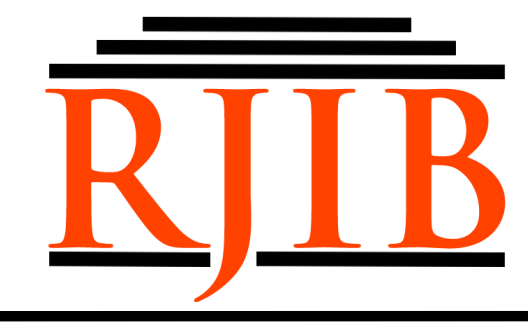

RETORIKA: Jurnal Ilmu Bahasa

Vol. 5, No. 1 April 2019, Page 1-6

\title{
Speech Function and Process in Fake News
}

P-ISSN: 2406-9019

E-ISSN: 2443-0668

Available Online at https://ejournal.warmadewa.ac.id/index.php/jret

Dian Zelina Fitriyani, Eddy Setia and Masdiana Lubis

University of Sumatera Utara, Indonesia

dianzelinaf@gmail.com

\begin{tabular}{|c|c|c|}
\hline Received: $17 / 10 / 2018$ & Revised: 14/12/2018 & Published: 30/04/2019 \\
\hline \multicolumn{3}{|c|}{ How to cite (in APA style): } \\
\hline \multicolumn{3}{|c|}{$\begin{array}{l}\text { Fitriyani, D, Z., Setia, E., \& Lubis, M. (2019). Speech Function and Process in Fake News. RETORIKA: Jurnal Ilmu } \\
\text { Bahasa, 5(1), 1-6. doi: http://dx.doi.org/10.22225/jr.5.1.836.1-6 }\end{array}$} \\
\hline
\end{tabular}

\begin{abstract}
This paper deals with speech function and process found in the fake news in social media Twitter. The data used in this research are 66 clauses in the tweets about political sessions updated by the Twitter account@makLambeTurah and analysed qualitatively by applying Systemic Functional Linguistics theory. The result of the analysis shows that the most dominant speech function found in the fake news in the social media is the "statement" with relational process as the highest appearance. It means that the fake news writer, as the support team of the candidate, uses "statement" in sharing ideas, information, and issues to the readers and expects the readers to receive them, and also persuades the readers to believe and change their mind. The result also reveals that such speech function and process happen due to the relational status between the fake news writer and the candidates (politicians) he supports, that is PDIP, and the context of situation, that is in the Regional Election 2018.
\end{abstract}

Keywords: speech function, process, fake news

\section{INTRODUCTION}

Fake news is not new, however, it has become a hot topic in 2017. Fake news has captured worldwide interest of people, and a number of organized efforts dedicated solely to fact-checking has almost tripled since 2014 (Mantzarlis, 2017). Fake news is fabricated news, stories or hoaxes created to deliberately misinform or deceive readers. Usually, these stories are created to either influence people's views, push a political agenda or cause confusion and can often be a profitable business for online publishers. Fake news stories can deceive people by looking like trusted websites or using similar names and web addresses to reputable news organisations.

Traditionally, news is got from trusted sources, journalists and media outlets that are required to follow strict codes of practice. However, the internet has enabled a whole new way to publish, share and consume information and news with very little regulation or editorial standards. Many people now get news from social media sites and networks and often it can be difficult to tell whether the stories are credible or not. Information overload and a general lack of understanding about how the internet works by people have also contributed to an increase in fake news or hoax stories.

The internet and social media have made it far easier for powerful entities to directly and quickly spread false or misleading information far and wide (Beville, 2017). There are many social medias in this world used to spread news, such as Facebook, Instagram, Twitter, Path, and etc. One of the social media sites which is often used to spread fake news is Twitter. Gil (2019), describes what Twitter is and how it works. He states that Twitter is an online news and social networking site where people communicate in short messages called "tweets". Twitter employs a purposeful message size restriction to keep things scan- 
friendly: every microblog 'tweet' entry is limited to 280 characters or less. He argues that this size capability promotes the focused and clever use of language, which makes tweets very easy to scan, and also very challenging to write well. This size restriction has really made Twitter as a popular social media (Gil, 2019).

In fact, most people use Twitter not only to tweet their feelings, opinions, or good news, but also to tweet and spread fake news. As stated by Utama and Bestari (2018), Twitter is the largest social media hoax spreader based on a study conducted by the Media Lab Institute of Technology Massachusetts, United States, which found that hoax dominates that social media about 70 percent (Utama \& Bestari, 2018). Worse, this fake account is retweeted by more users than the original news. By using their words, they tell lies and influence other people's mind. This is very dangerous as it can give bad effect for the certain people because of the fake news.

Recently, Indonesia holds Simultaneous Regional Election 2018 in 17 provinces, 115 districts and 39 cities. In this situation, political session becomes a hot topic in every media, including social media such as Twitter. Especially in the campaign period posted officially by General Election Commision website, February 15, 2018 until July 23, 2018, the news (real or fake) about the candidates and political parties spread widely through media. Twitter plays a role in spreading that news in order to persuade people and influence their mind and belief toward their selection. In this research, the fake news about the political session in the campaign period spreaded through Twitter account @makLambeTurah which will be discussed further.

The Twitter account @makLambeTurah is very active in spreading fake news and hateing speech which can be seen from the intensity of uploading tweets about 15-20 tweets in a day. The data below show the tweets containing political sessions uploaded by a Twitter account user @makLambeTurah.

Tweet 1 (Uploaded at July 20, 2018)

Pak Prabowo pasti lebih condong ke Demokrat daripada PKS mengingat hasil Pilkada 2015 dan 2018, calon2 PKS terpuruk. Beda dengan demokrat yang memenuhi target. Jadi Prabowo-Ani Yudhoyono lebih seru.

(Mr. Prabowo tends to the Democrats than the PKS with reference to the results of the elections 2015 and 2018, the candidates of PKS are slumped. Unlike the Democrats who meet targets. So, Prabowo-Ani Yudhoyono was more exciting.).

The data in this research contain features of political discourse. The specific characteristics of a political discourse are the following 4 features: 1) agonistic ability; 2) aggressiveness; 3 ) ideological character; and 4) theatricality (Kenzhekanova, 2015).

The current researches about speech function analysis offer an analysis in dialogue, text book, and talk show based on the Systemic Functional Linguistics theory by (Arifuddin \& Sofwan, 2015; Halliday, 1994; Halliday \& Matthiessen, 2004; Kimps, Davidse, \& Cornillie, 2014; Siregar, 2017). Therefore, it is important to do this research in the fake news in an attempt to delve the way of the fake news writer in communicating his mind and sharing messages. This research tries to analyse the speech function and process found in the fake news in social media, and why such speech function and process are realised in the way as they are by applying Systemic Functional Linguistics theory by (Halliday \& Matthiessen, 2014).

\section{METHOD}

The data used in this research are 66 clauses found in the tweets about political sessions updated by the Twitter account @makLambeTurah during the campaign period, February 15, 2018 until July 23, 2018. The data are in Indonesian language, and it is translated into English. The social media account@makLambeTurah has been reported to the Criminal Investigation Agency of the Headquarters of the Indonesian National Police for the action of sharing fake news through its tweets (Hantoro, 2018). It makes this Twitter account becomes the source of data in this research.

The data are collected by there three steps in analyzing the data after the process of data collecting, namely (Miles, Huberman, \& Saldana, 2014): (1) data condensation, (2) data display, and (3) drawing and verifying conclusions. In analysing the data, Systemic Functional Linguistics theory by Halliday and Matthiessen (2014) is applied to analyse the speech function and process in the fake news in order to delve the way of the fake news writer in communicating his mind and sharing messages (Halliday \& Matthiessen, 2014).

\section{RESULT AND DISCUSSION}

Speech function into four kinds, they are 
statement, question, offer, and command (Halliday \& Matthiessen, 2014). The statement is realised as declarative and a question as interrogative. A command is usually cited, in grammatical examples, as imperative, while for offers there is no distinct mood category, since it can be realised by the three mood, declarative, interrogative, or imperative. Based on the data analysis, the followings are the finding and the discussion of speech function in the fake news in social media.

Table 1

Speech function found in the fake news in social media

\begin{tabular}{ccc}
\hline Speech Function & Amount & Percentage \\
\hline Statement & 60 & $90.91 \%$ \\
Question & 1 & $1.51 \%$ \\
Offer & 0 & $0 \%$ \\
Command & 5 & $7.58 \%$ \\
Total & 66 & $100 \%$ \\
\hline
\end{tabular}

Statement, as the highest appearance, means that speech deals with giving information to the audience or reader. Statement is a way of giving information by stating or the act of stating in speech and writing. Giving means invite to receive. When the fake news writer shares something in the form of statement, it means that the writer expected the readers to receive the information he wants to share and also persuades the readers to believe or do something.
The characteristic expression of a statement is the declarative which is realised by the "subject" and followed by "verb" (Halliday \& Matthiessen, 2014). Statement shows the person or the topic (Mood) being talked is the main issue in the fake news. In this case, the person or the topic is related to the candidates in the Regional Election 2018, especially between the PDIP proponent and Gerindra proponent, as described in the following examples:

Table 2.

1.A. Pak Prabowo pasti lebih condong ke Demokrat daripada PKS mengingat hasil Pilkada 2015 dan 2018

\begin{tabular}{ccc}
\hline Pak Prabowo & pasti lebih condong ke & $\begin{array}{c}\text { Demokrat daripada PKS mengingat hasil } \\
\text { Pilkada 2015 dan 2018, }\end{array}$ \\
\hline Subject & Verb (Predicator) & Complement \\
MOOD & & RESIDUE \\
\hline
\end{tabular}

Table 3

1.B. Mr. Prabowo tends to the Democrats than PKS with reference to the results of the Regional Election 2015 and 2018

\begin{tabular}{ccc}
\hline Mr. Prabowo & tends to & $\begin{array}{c}\text { the Democrats than PKS with } \\
\text { reference to the results of the Regional } \\
\text { Election 2015 and 2018, }\end{array}$ \\
\hline Subject & $\begin{array}{c}\text { Verb } \\
\text { (Predicator) }\end{array}$ & Complement \\
MOOD & & RESIDUE \\
\hline
\end{tabular}

Table 4

56.A. Program kerja yang ditawarkan DJOSS ini sangat menarik terutama reformasi birokrasi

\begin{tabular}{ccc}
\hline $\begin{array}{c}\text { Program kerja yang } \\
\text { ditawarkan DJOSS ini }\end{array}$ & (terdengar) & $\begin{array}{c}\text { sangat menarik terutama } \\
\text { reformasi birokrasi }\end{array}$ \\
\hline Subject & $\begin{array}{c}\text { Verb } \\
\text { (Predicator) }\end{array}$ & Complement \\
MOOD & & RESIDUE \\
\hline
\end{tabular}


Table 5

56.B. The work program offered by DJOSS is very interesting, especially the bureaucratic reform

\begin{tabular}{ccc}
\hline $\begin{array}{c}\text { The work program } \\
\text { offered by DJOSS }\end{array}$ & is & very interesting, especially the bureaucratic reform \\
\hline Subject & $\begin{array}{c}\text { Verb } \\
\text { (Predi } \\
\text { cator) }\end{array}$ & Complement \\
MOOD & RESIDUE \\
\hline \multicolumn{3}{c}{ Table 6 } \\
61.A. Program unggulan dari DJOSS adalah kartu Sumut Pintar (KSP) \\
\hline $\begin{array}{c}\text { Program unggulan } \\
\text { dari DJOSS }\end{array}$ & adalah & kartu Sumut Pintar (KSP), \\
\hline Subject & $\begin{array}{c}\text { Verb } \\
\text { (Predicator) }\end{array}$ & Complement \\
MOOD & & RESIDUE \\
\hline
\end{tabular}

Table 7

61.B. The flagship program of DJOSS is the Sumut Pintar card

\begin{tabular}{ccc}
\hline $\begin{array}{c}\text { The flagship program of } \\
\text { DJOSS }\end{array}$ & is & the Sumut Pintar card, \\
\hline Subject & $\begin{array}{c}\text { Verb } \\
\text { (Predicator) }\end{array}$ & Complement \\
MOOD & & RESIDUE \\
\hline
\end{tabular}

From the examples above, it can be seen that the mood is the main issue being focused by the fake news writer to be shared to the readers. The fake news writer gives some bad or good evaluations about the candidates of the Regional Election 2018, in order to influence the readers' mind and belief.

Thus as well as being a mode of action or rather of interaction: of giving and demanding goods-\&-services and information, the clause is also a mode of reflection, of imposing linguistic order on our experience of the endless variation and flow of events. The grammatical system by which this is achieved is that of Transitivity. Therefore, the transitivity analysis is also important to do in this research. However, this research only focuses on the process.

As stated before in chapter two, divide process into six types, they are (1) material process with the participants "Actor and Goal", (2) behavioural process with the participant "Behaver", (3) mental process with the participants "Senser and Phenomenon", (4) verbal process with the participants "Sayer and Target/Receiver/Verbiage", (5) relational process with the participants "Carrier and Attribute, also Token and Value", and (6) existential process with the participant "Existent" (Halliday \& Matthiessen, 2014). Based on the data analysis, the following is the finding and the discussion of process in the fake news in social media.

Table 8

Process found in the fake news in social media

\begin{tabular}{ccc}
\hline Process Type & Amount & Percentage \\
\hline Material & 19 & $28.79 \%$ \\
Behavioural & 0 & $0 \%$ \\
Mental & 11 & $16.66 \%$ \\
Verbal & 8 & $12.12 \%$ \\
Relational & 26 & $39.4 \%$ \\
Existential & 2 & $3.03 \%$ \\
Total & 66 & $100 \%$ \\
\hline
\end{tabular}


Relational process, as the highest appearance, represents the relation between the fake news writer and the candidates whom he supports. There are two reasons which can be explained related to the usage of relational process in this fake news. First, to give an attribute or a value to the politicians as the support team, in order to make the candidates win the Regional Election 2018 by giving statements to persuade the readers or change the readers' mind. Second, to give an attribute or a value to the other politicians, as the rival in the Regional Election 2018, in order to defeat the rival by giving statement to deceive the readers' mind and change their belief. It is in line with the most dominant speech function found in the fake news, that is "Statement". The examples of relational process can be seen in the following examples:

Table 9

4.A. Jadi Prabowo-Ani Yudhoyono lebih seru

\begin{tabular}{cccc}
\hline Jadi & Prabowo-Ani Yudhoyono & (menjadi) & lebih seru \\
\hline Conj. & Carrier & Pr: Relational & Attribute \\
\hline
\end{tabular}

Table 10

4.B. So, Prabowo-Ani Yudhoyono is more exciting

\begin{tabular}{cccc}
\hline So, & Prabowo-Ani Yudhoyono & is & more exciting \\
\hline Conj. & Carrier & Pr: Relational & Attribute \\
\hline
\end{tabular}

Table 11

56.A. Program kerja yang ditawarkan DJOSS ini sangat menarik terutama reformasi birokrasi

\begin{tabular}{ccc}
\hline $\begin{array}{c}\text { Program kerja yang } \\
\text { ditawarkan DJOSS ini }\end{array}$ & (terdengar) & $\begin{array}{c}\text { sangat menarik terutama } \\
\text { reformasi birokrasi }\end{array}$ \\
\hline Carrier & Pr: Relational & Attribute \\
\hline
\end{tabular}

Table 12

56.B. The work program offered by DJOSS is very interesting, especially the bureaucratic reform

\begin{tabular}{ccc}
\hline $\begin{array}{c}\text { The work program } \\
\text { offered by DJOSS }\end{array}$ & is & $\begin{array}{c}\text { very interesting, especially the } \\
\text { bureaucratic reform }\end{array}$ \\
\hline Carrier & Pr: Relational & Attribute \\
\hline
\end{tabular}

Table 13

61.A. Program unggulan dari DJOSS adalah kartu Sumut Pintar (KSP)

\begin{tabular}{ccc}
\hline Program unggulan dari DJOSS & adalah & kartu Sumut Pintar (KSP), \\
\hline Token & Pr: Relational & Value \\
\hline
\end{tabular}

Table 14

61.B. The flagship program of DJOSS is the Sumut Pintar card,

\begin{tabular}{ccc}
\hline The flagship program of DJOSS & is & The Sumut Pintar card, \\
\hline Token & Pr: Relational & Value \\
\hline
\end{tabular}

From the examples above, it can be seen that the fake news writer supports the candidate that is carried by the PDIP. It, then, shows the relation between the fake news writer and the candidate he supports or he does not. In this case, the fake news writer mostly shares informations and gives good evaluations toward the candidate that is carried by the PDIP. It means that the fake news writer is pro to the PDIP.
Relational process shows the attitude, value, and emotion of somebody or toward something which is one of the characteristics of the fake news. Relational process is the most dominant process found in the fake news with $39.4 \%$ appearance, and followed by mental process with $16.66 \%$ appearance which also shows the attitude and emotion of somebody. If the total of relational process and mental process is combined together, it will be half of 
the news, that is $56.06 \%$. Therefore, it makes the news shared by the Twitter account (a)makLambeTurah is fake news.

\section{IV.CONCLUSION}

After analysing the speech function and process in the fake news in social media, there are some conclusions that can be drawn. Statement, as the most dominant speech function found in the fake news, means that speech deals with giving information to the audience or reader. Giving means invite to receive. When the fake news writer shares something in the form of statement, it means that the writer expected the readers to receive the information he wants to share and also persuades the readers to believe or do something. It is in line with the most dominant process found in the fake news, that is Relational process. It shows a connection between them. Relational process represents the relation between the fake news writer and the candidates he supports. First, as the support team and second, as the rival for other candidates. The fake news writer supports the team and defeat the opponent by giving information, fake news to deceive the readers' mind and change their belief. To do so, the speech function used is "Statement".

The result of the analysis shows that such speech function and process happen due to the status of the fake news writer and the candidates (politicians) he supports, and the context of situation. It is clearly seen that both the fake news writer and the candidates (politicians) come from the same party, that is PDIP. Therefore, the fake news writer supports anyone who comes from PDIP. He tries to get more votes for his candidates by evaluating people's behaviour and other things related to the candidates in the Regional Election 2018.

In this case, the context of situation is in the Regional Election 2018, where the representatives of PDIP take place in the Regional Election 2018. It is clearly seen that the fake news writer supports Djarot Saiful Hidayat-Sihar Sitorus (DJOSS) carried by PDIP, and tries to strike down the rival of DJOSS, that is Edy Rahmayadi-Musa Rajekshah (ERAMAS) carried by Gerindra, Golkar, Nasdem, and Perindo, for the next Governor of North Sumatera.

\section{REFERENCES}

Arifuddin, M., \& Sofwan, A. (2015). Speech Functions And Grammatical Patterns Realization In Conversation In The English
Textbook. Lembar Ilmu Kependidikan: Journal of Educational Research, 44(1), 1-6.

Beville, B. (2017). Fake News \& the Importance of Information Literacy. Retrieved from https:// blogs.proquest.com/general/fake-news-theimportance-of-information-literacy/

Gil, P. (2019). What Is Twitter \& How Does It Work? Retrieved from https:// www.lifewire.com/what-exactly-is-twitter2483331

Halliday, M. A. . (1994). An Introduction to Functional Grammar (Second). London: Edward Arnold.

Halliday, M. A. ., \& Matthiessen, C. M. I. . (2004). An Introduction to Functional Grammar (Third Revi). London: Edward Arnold.

Halliday, M. A. ., \& Matthiessen, C. M. I. . (2014). Introduction to Functional Grammar (fourth Rev). New York: Routledge.

Hantoro, J. (2018). Fadli Zon Laporkan Akun Ananda Sukarlan dan@makLambeTurah. Retrieved from https://nasional.tempo.co/ $\mathrm{read} / 1066106 /$ fadli-zon-laporkan-akunananda-sukarlan-dan-maklambeturah

Kenzhekanova, K. K. (2015). Linguistic Features of Political Discourse. Mediterranean Journal of Social Sciences, 6(6), 192-199. https:// doi.org/10.5901/mjss.2015.v6n6s2p192

Kimps, D., Davidse, K., \& Cornillie, B. (2014). A speech function analysis of tag questions in British English spontaneous dialogue. Journal of Pragmatics, 66, 64-85.

Mantzarlis, A. (2017). There are now 114 factchecking initiatives in 47 countries. Retrieved from https:/www.poynter.org/factchecking/2017/there-are-now-114-factchecking-initiatives-in-47-countries/

Miles, M. ., Huberman, A. ., \& Saldana, J. (2014). Qualitative Data Analysis: A Methods Sourcebook (Third). Los Angeles: SAGE Publications.

Siregar, U. N. (2017). Speech Function and Move in Rumah Uya Talk Show. International Journal of Language Learning and Applied Linguistics World, 16, 57-66.

Utama, L., \& Bestari, N. P. (2018). Twitter, Media Sosial Penyebar Hoax Terbesar. Retrieved from https://www.viva.co.id/arsip/1014660twitter-media-sosial-penyebar-hoax-terbesar 